\title{
ABSTRACTS
}

This section of the JoURNAL is published in collaboration with the three abstracting Journals, ABSTRACTS OF World Medicine, Abstracts of World Surgery, Obstetrics, and Gynaecology, and Ophthalmic LITERATURe, published by the British Medical Association. The abstracts are divided into the following sections: Syphilis, (General, Pathology, Therapy); Gonorrhoea (General, Pathology, Therapy) ; Chemotherapy; Other Venereal Disease Conditions; Public Health; Miscellaneous. After each subsection of abstracts follows $a$ list of articles that have been noted but not abstracted. All subsections will not necessarily be represented in each issue.

\section{SYPHILIS (Gencral)}

Diagnosis of Tertiary Syphilis of the Liver : 25 Years after McCrae. ShAPIRO, E., and WeINER, H. (1951). Amer. J. med. Sci., 222, 494.7 refs.

The difficulties of diagnosis in cases of tertiary syphilis of the liver are ably summarized in a full description of a case of obscure abdominal disease in a woman aged 66 who suffered from recurrent haematemesis and ascites over a period of years. Eventually necropsy revealed the typical hepar lobatum of tertiary syphilis. The various signs, symptoms, and pathology of this condition are analysed and discussed from the authors' experience of 79 cases, and in relation to the series of cases reported by McCrae and by Hahn. Syphilitic lesions were found in other organs in 31 cases. The authors find that enlargement of the liver is not as frequent as is commonly believed. Jaundice, if present, is of slight degree. Vascular cutaneous spider naevi, common in nutritional cirrhosis, are rare in hepar lobatum.

V. E. Lloyd

Problems of Syphilisin Pregnancy. (Probleme der Schwangerenlues.) MülLER, M. (1951). Derm. Wschr., 124, 1217. 18 refs.

Focal Translucences of the Skull Bones in Early Syphilis. (Herdförmige Aufhellúngen der Schädelknochen bei Fruhsyphilis.) Pfister, R. (1951). Arch. Derm. Syph., Wien, 193, 143. 4 figs, 11 refs.

Statistical Study of 240 Cases of Syphilitic Cardiovascular Disease in India. VAKIL, R. J. (1951). Indian Heart J., 3, 133 . 30 refs.

Syphilis and Tuberculosis. (Syphilis und Tuberkulose.) Streitmann, B. (1951). Klin. Med., 6, 527. 43 refs.

Transfusion Syphilis. (Die Tranfusions-Syphilis.) HEIM, W. (1952). Med. Welt. 10, 319.1 fig., 34 refs.

Latent Syphilis. (La syphilis occulte.) DEsneux, J. (1952). Scalpel, 105, 28.

Congenital Syphilis. Kessel, I. (1952). S. Afr. J. med. J., 26, 1. 7 figs.
CongenitalSyphilis. ("Lues acquisita infantum.") GuMPESBERGER, G. (1952). Öst.Z. Kinderheilk., 7, 77. 20 refs.

Prenatal Syphilis in One of Twins. RaJam, R. V., and Rangiah, P. N. (1952). J. Indian med. Ass., 21, 186. 7 figs, 6 refs.

\section{SYPHILIS (Pathology)}

False Positive Serum Reactions for Syphilis in Martinique (Syphiloid Reactions). (Les fausses réactions sérologiques de la syphilis à la Martinique (Les réactions syphiloïdes.) Montestbuc, E., BLACHE, R., and Labarde, R. (1951). Ann. Derm. Syph., Paris, 78, 572. 8 refs.

This paper contains a short discussion of the causes of false-positive reactions in serum tests for syphilis. The authors find that the following diseases (in this order of frequency) may be accompanied by false-positive syphiloid reactions : yaws, tropical ulcer, pinta (not yet positively identified in Martinique), filariasis, cutaneous leishmaniasis, leprosy, and gangosa. Of 143 native military recruits, free from any sign of syphilis, filariasis, or tropical ulcer, 78 gave positive reactions to serum tests for syphilis. Of these, 29 were retested after 2 months, and in eighteen the results were still positive. The authors consider that these results indicated the presence of syphiloid affections, and stress the importance, especially in tropical areas, of not relying on serum tests alone in the diagnosis of syphilis. James Marshall

Electronmicrography of Treponemata from Cases of Yaws, Pinta, and the so-called Cuban Form of Pinta. Angulo, J. J., Watson, J. H. L., Wedderburn, C. C., Leon-Blanco, F., and Varela, G. (1951). Amer. $J$. trop. Med., 31, 458.24 figs, 22 refs.

Treponema pertenue, $T$. carateum, and $T$. pallidum are all indistinguishable from each other under the light microscope. Material from a Jamaican case of yaws, a Mexican case of pinta, and a Cuban case of the Cuban form of pinta was therefore examined by electronmicroscopy.

Except for the fact that no flagella were seen on the thirty specimens of $T$. pertenue examined (which the authors mention might have been owing to artefact) no 
differences in morphology were observed between the treponemata from the three different cases. $\quad R$. Hare

Development of Treponemal Immobilizing Antibodies in Mice following Injection of Killed Treponema pallidum (Nichols Strain). MCLEOD, C. P., and Magnuson, H. J. (1951). J. vener. Dis. Inform., 32, 274. 10 refs.

The study of immunity in syphilis by the artificial immunization of rabbits has been consistently unsuccessful : sera of infected rabbits possessed no agglutinating, complement-fixing, or protective antibodies against specific treponemal suspensions. Instead of rabbits, therefore, white mice were inoculated intraperitoneally with spirochaetes from the testicles of rabbits with syphilitic orchitis. Mice inoculated with a single dose of $8,000,000$ organisms and bled 7 weeks later failed to produce antibodies. Some of these mice then received three additional injections, 2 weeks apart, to a total of $16,000,000$ spirochaetes. When they were bled 1 week later positive immobilizing antibodies were demonstrated in vitro by the method of Nelson and Mayer. This development of antibodies was thought to be not a function of time but to depend upon the number of spirochaetes originally injected. Also, immobilizing antibodies were found to be produced by inoculating the mice with killed spirochaetes. The antigenic material in the spirochaetes was unaffected by exposure to 0.4 per cent. " mapharsen " (oxophenarsine) for $75 \mathrm{~min}$, and was relatively heat stable at $56^{\circ} \mathrm{C}$. but was destroyed by heating at $70^{\circ} \mathrm{C}$. for $40 \mathrm{~min}$. The mapharsen-killed spirochaetes were more antigenic than the heat-killed organisms and antigenicity was not perceptibly reduced by prolonging the heating time at $56^{\circ} \mathrm{C}$. from 40 to 80 min. Mice inoculated with $12,000,000$ living, mapharsenkilled or heat-killed spirochaetes developed immobilizing antibodies in less than 2 weeks.

The ability to produce antibodies against $T$. pallidum in animals by the inoculation of killed organisms and without a concurrent syphilitic infection provides a new tool for the study of the antigenic structure of this organism.

T. Anwyl-Davies

Study of Immunity in Experimental Syphilis as demonstrated by Contact Exposure Challenge. MCLEOD, C. P., and ARnold, R. C. (1951). J. vener. Dis. Inform., 32, 279.4 refs.

In order to demonstrate that a state of complete resistance arises in early syphilis and may persist for periods up to 20 months, the genital mucous membrane of rabbits was exposed to contact with suspensions of virulent Treponema pallidum. Cotton pledgets soaked in the spirochaete suspension were inserted into the preputial sac of each animal and kept in position for 1 hour with haemostatic forceps. A measured drop $(0.1 \mathrm{ml}$.) of the suspension was added to the cotton wool every 20 minutes so that approximately 3,000,000 spirochaetes were in contact with the genital mucous surfaces during the hour. For the next 4 months the rabbits were examined twice weekly and the specificity of lesions was proved by dark-field examinations. At the end of this time lymph node transfers from those animals which failed to develop lesions were made into the scrotum of normal rabbits.

On 22 rabbits with early active syphilis, twenty were immune when challenged by contact exposure 10 days after the completion of a curative course of treatment with penicillin ; of fifteen rabbits, eleven were immune 6 months after treatment; and of twenty rabbits, eighteen were immune 8 months after treatment. Of thirteen rabbits with latent syphilis, twelve were immune when challenged by contact exposure 6 months after treatment. In one group of rabbits with early active syphilis which were challenged by contact exposure at 8 and 20 months after termination of the original infection, eleven of sixteen rabbits were immune to both challenges and five were immune to the first, but were infected by the second. In a group of rabbits with latent syphilis which were challenged by re-inoculation, at 1 and 2 years after termination of the original infection, five of eleven rabbits were immune to both challenges, four were infected by the first, but were immune to the second, and two were infected by both.

It was shown that by the contact method a state of complete resistance arises in early syphilis during the active stage of the disease and persists for 6 to 20 months after termination of the original infection; and that by inoculation the duration of immunity following latent syphilis was comparable with that after early syphilis as demonstrated by contact challenge. T. Anwyl-Davies

Practical Value of the "Behring Works Rapid Syphilis Test." (Ưber die Brauchbarkeit des " Luesschnelltest Behringwerke.") WARnecke, B., and FAlliner, H. (1951). Z. ImmunForsch., 108, 481. 11 refs.

Harrisưv's Microflocculation Test for Treponema. (Harrisův microflokulačni test na prijici.) KRAUS, Z. (1951). Lek. Listv., 6, 654. 14 refs.

Cardiolipin, a New Antigen for the Biological Diagnosis of Syphilis ; a Survey. (Cardiolipin en nyt Antigen til Avendelse ved Serodiagnosen af Syfilis en Oversigt.) ReYN, A., and Schmidt, H. (1951). Ugeskr. Laeg., 113, 1427. Bibl.

Antigens in Syphilis. Value of the Spicca Test. (Gli antigeni luetici al vaglio della reazione Spicca.) DE LuCA, A., and Montilli, G. (1951). Ann. ital. Derm. Sif., 6, 78.1 ref.

Non-Specific Syphilis Reactions. (Ưber unspezifische Luesreaktionen.) Gross, H. (1951). Ärztl. Wschr., 6, 1095. 11 refs.

Value of Cardiolipin Reactions in the Serodiagnosis of Congenital Syphilis in Infancy. [In English.] SELLEK, A., Del Frade, A., and Martinez, A. (1951). Rev. cubana Lab. clin., 4, 307. 24 refs. 
Syphilis-conditioned Sensitization to a " Silent" Antigen. (Luesbedingte Sensibilisierung gegen ein "stummes" Antigen.) Prokop, O., Roth, F., and LANGENDÖRfER, G. (1951). Z. ImmunForsch., 108, 520. 6 refs.

\section{SYPHILIS (Therapy)}

Treatment of Syphilis in Mother and Child and its Results. (Die Behandlung der Lues bei Mutter und Kind und deren Ergebnisse.) MaYer, J. B., and Herkenhoff, H. F. (1951). Ann. paediatr., Basel, 177, 194. Bibl.

The authors present a survey of 151 cases of congenital syphilis in newborn children, observed at the University Children's Hospital, Hamburg-Eppingen, during the years 1945-50. They point out that the incidence of congenital syphilis is on the increase; seventy of the mothers were not aware of the fact that they were syphilitics until the disease was diagnosed in the infants. Therefore the authors urge that a routine Wassermann test for all expectant mothers be performed. Of the present series, 36 mothers had had antisyphilitic treatment during pregnancy ; in spite of this the lesson learnt and discussed is that the newborn should be given treatment immediately after birth if the mother has been sero-negative for less than 3 years, or if maternal syphilis is first discovered during pregnancy.

The present-day treatment of pregnant women is briefly discussed, and the respective value of arsenotherapy and penicillin compared. Because of the rarer incidence of side-effects and shorter duration of treatment the authors prefer penicillin. They have come to the conclusion that the Herxheimer reaction does not follow an "all or none" law but that the reaction is proportionate to the penicillin dosage. They therefore recommend a treatment schedule beginning with 500 units 3-hourly for 2 days, working up gradually to 25,000 units 3 -hourly on the 17 th day and continuing until a total of 3.5 mega units has been given. This is followed by a 15-day course of 300,000 units daily of depot penicillin, and then by a course totalling $40 \mathrm{~g}$. of "spirocid" (acetarsol), and later on by another 20-day course of 300,000 units daily of depot penicillin. There is no danger of a Herxheimer reaction after the first course of treatment.

Ferdinand Hillman

\section{Preventive Treatment of Congenitally Syphilitic Children born of Treated Mothers. (Zur Präventiv-behandlung connatalluetischer Kinder bereits vorbehandelter Mütter.) FALK, W., and KirCHER, W. (1951). Med. Klinik., 46, 1052.}

A survey is given of the results of antisyphilitic treatment of women before and during pregnancy. It is pointed out that infants born of mothers who were treated before pregnancy may seem at first sight to be free of syphilitic symptoms, and that often typical symptoms of prenatal syphilis are revealed only after careful examination, including radiography. In the present series of 72 infants, only 21 were found to be entirely free of syphilis. The majority of the infected children belonged to mothers who had been treated only before pregnancy and not during it. More than 40 per cent. of the children had positive serologic reactions. The most frequent organic change was periostitis, though this alone could not be considered a definite symptom of prenatal syphilis ; the majority of cases, however, showed other syphilitic symptoms, such as enlargement of the liver and spleen. As a result of these findings it is urged that all children born to mothers with a history of syphilis at any time should receive antisyphilitic treatment whether they show the stigmata of the disease or not. Treatment is discussed in detail.

K. E. Hein

Penicillin in Peanut Oil and Beeswax for the Treatment of Early Syphilis. Bundesen, H. N., RodriquEZ, J., Schwemlein, G. X., Parkhurst, G. E., and WeinSTEIN, S. (1951). Brit. J. Derm., 63, 302.

This paper from the Venereal Disease Treatment Centre, Chicago, compares the result of two different treatment schedules using penicillin in a delayed absorption medium on two similar groups of patients suffering from acute syphilis. All were given 600,000 units intramuscularly of calcium penicillin in peanut oil with 4 per cent. beeswax at 24-hour intervals. Group A (98 cases) received eight injections totalling 4,800,000 units in 8 days; and Group B (67 cases) had sixteen injections totalling, 9,600,000 units in 16 days. All these patients had dark-field positive lesions, and about 80 per cent. of them were observed over a period of 12 to 15 months. Group A comprised twenty cases of sero-negative and twenty cases of sero-positive primary syphilis, 56 cases of secondary syphilis, and two of relapsing secondary syphilis. In Group B, nine patients were treated for sero-negative and thirteen for seropositive primary syphilis, $\mathbf{4 3}$ for secondary syphilis, and two for relapsing secondary syphilis.

In Group $A$ the cumulative percentage of successful results was 86.2 per cent., against 87.7 per cent. in Group B. As the stage of disease before treatment might have biased the figures, a more accurate comparison was made by analysing the secondary cases. In Group A, the failure rate for 56 cases was $15 \cdot 2$ per cent. against 18.6 per cent. for 43 cases in Group B. In a group of 159 secondary patients who received a total of 4,800,000 units of aqueous crystalline benzyl penicillin over $7 \frac{1}{2}$ days at intervals of 3 hours, the failure rate was 14 per cent. In a similar group of 136 patients who received the same total amount of penicillin at 2-hourly intervals, the failure rate was 15 per cent.

It is concluded that single daily injections of penicillin with oil and beeswax are nearly as effective as multiple daily injections, provided that the same total amount of penicillin over the same period is given. Also, that increasing the time of administration of the penicillin from 8 to 16 days and doubling the amount of penicillin from 4.8 to 9.6 mega units had no further beneficial effect.

T. Anwyl-Davies 